\title{
ArcheoSciences
}

Revue d'archéométrie

\section{Preparation of Pleistocene Human Bones with an Ultrasonic Scaler: The Case of Mandible ATD6-112 from Atapuerca (Spain)}

Préparation des os humains pléistocènes à l'aide d'un détartreur à ultrason : le cas de la mandibule ATD6-112 d'Atapuerca (Espagne)

L. López-Polín, J. M. Bermúdez de Castro and E. Carbonell

\section{OpenEdition}

Journals

\section{Electronic version}

URL: https://journals.openedition.org/archeosciences/3283

DOI: $10.4000 /$ archeosciences.3283

ISBN: 978-2-7535-1849-0

ISSN: $2104-3728$

Publisher

Presses universitaires de Rennes

Printed version

Date of publication: 30 April 2011

Number of pages: $235-239$

ISBN: $978-2-7535-1847-6$

ISSN: 1960-1360

Electronic reference

L. López-Polín, J. M. Bermúdez de Castro and E. Carbonell, "Preparation of Pleistocene Human Bones with an Ultrasonic Scaler: The Case of Mandible ATD6-112 from Atapuerca (Spain)", ArcheoSciences [Online], 35 | 2011, Online since 30 April 2013, connection on 01 March 2022. URL: http:// journals.openedition.org/archeosciences/3283 ; DOI: https://doi.org/10.4000/archeosciences.3283 


\title{
Preparation of Pleistocene Human Bones with an Ultrasonic Scaler: The Case of Mandible ATD6-112 from Atapuerca (Spain)
}

\author{
Préparation des os humains pléistocènes à l'aide d'un détartreur à ultrason : \\ le cas de la mandibule ATD6-112 d'Atapuerca (Espagne)
}

\author{
L. López-Polín*, **, J. M. Bermúdez de Castro*** and E. Carbonell*, **, ****
}

\begin{abstract}
The preparation of recently recovered fossil bones often consists of removing sediment by means of mechanical cleaning. A variety of tools are commonly employed in this process (hammers and chisels, air abrasion devices, pneumatic engraving pens, etc). Another tool, however, has received less attention in the literature: the ultrasonic scaler. An ultrasonic scaler is an ultrasonic device used by dentists to remove hard calculus deposits and stains from the teeth. In this article, we describe the preparation of the human mandible ATD6-112 from the Pleistocene site of Gran Dolina (Atapuerca, Spain) with an ultrasonic scaler. This article aims to describe the advantages and drawbacks of this tool for use in some cleaning processes.
\end{abstract}

Résumé : La préparation des ossements fossiles récemment découvert dans les sites archéologiques, consiste souvent à enlever le sédiment par nettoyage mécanique. Pour cela, une variété d'outils a été largement utilisée (marteaux et burins, dispositifs d'abrasion d'air, stylos pneumatiques). Moins rapportée, est l'utilisation d'un détartreur ultrasonique (un appareil à ultrasons utilisé par les dentistes pour enlever le tartre et les taches des dents). Dans cet article, nous décrivons la préparation réussie de la mandibule humaine ATD-112 du site archéologique pléistocène de Gran Dolina (Atapuerca, Espagne) par détartreur ultrasonique. Cet article vise à exposer les avantages et les inconvénients de cet outil à des fins de nettoyage.

Keywords: Conservation, fossil preparation, ultrasonic scaler, Atapuerca.

Mots clé : Conservation-restauration, préparation d'os fossile, détartreur ultrasonique, Atapuerca.

\section{INTRODUCTION}

Fossil remains found in limestone caves frequently display problems related to the presence of calcium carbonate, which precipitates and hardens the sediment of the cave.
Because of its hardness, the sediment often has to be broken with great force. In fact, excavation is often the most critical moment for the remains; even material in good condition can suffer serious alterations due to the enclosing matrix (López-Polín et al., 2008). Thus, it is common for the prepa-

\footnotetext{
* Institut Català de Paleoecologia Humana i Evolució Social (IPHES), C/Escorxador s/n, 43003 Tarragona, Spain. (lucia.lopezpolin@iphes.cat)

** Àrea de Prehistòria, Universitat Rovira i Virgili (URV), Avinguda de Catalunya 35, 43002 Tarragona, Spain

*** Centro Nacional de Investigación sobre Evolución Humana (CENIEH), Paseo Sierra de Atapuerca s/n, 09002 Burgos, Spain. (josemaria.bermudezdecastro@cenieh.es)

****Visiting professor, Institute of Vertebrate Paleontology and Paleoanthropology of Beijing (IVPP). (eudald.carbonell@urv.cat)
} 
ration laboratory to receive fossils that are either embedded in hard matrices or broken as a result of the excavation process. Mechanical tools are normally used to prepare such specimens. Preparation by means of mechanical methods has been widely reported, including the use of chisels, pneumatic engraving pens (also referred to as pneumatic scribes or engravers) and air abrasion devices (e.g. May et al., 1994; Wilson, 1995). For this mandible we needed a tool that would provide a degree of precision close to that of a scalpel in order to clean the finer parts of the fossil (an immature mandible has many thin parts, especially in the alveolar process) but that, at the same time, would be powerful enough to break the matrix. In this case we ultimately chose the ultrasonic scaler. This device has certainly been used in many conservation or preparation projects; specifically, it has been referred to in relation to the preparation of microvertebrates in fossil preparation handbooks (e.g. Rixon, 1976; May et al., 1994; Green, 2001) and articles (such as Jakobsen \& Feldman, 2004), but has rarely been described in detail (with some exceptions, such as Fedak, 2000). The description of this case, demonstrating some of the advantages and disadvantages that we have experienced during the preparation of this fossil, aims to contribute to the body of knowledge about the ultrasonic scaler as a potential tool for use in the preparation of fossils.

\section{Materials and Methods}

Here we present the preparation treatment of a hominin mandible from level TD6 of the Gran Dolina site (Sierra de Atapuerca, Burgos, Spain), which dates to between 0.8 and 0.9 million years ago (Parés \& Pérez-González, 1995; Falguères et al., 1999; Berger et al., 2008). Many human remains associated with fauna and lithics have been recovered in this level (Carbonell et al., 1995; Carbonell et al., 1999) and the hominin fossils have been attributed to the species Homo antecessor (Bermúdez de Castro et al., 1997).

The specimen identified as ATD6-112, whose treatment we describe here, was recovered during the 2006 field season. It is the right half mandible of an immature individual that preserves some teeth in place at different stages of development (i.e. germens, deciduous and permanent teeth). It has provided valuable information about the development pattern of the species (Bermúdez de Castro et al., 2010).

The mandible (ATD6-112) arrived at the conservation laboratory broken into six pieces (Fig. 1). Some of these pieces were firmly embedded in a hard sediment mass strongly adhered to the material, while others were only partially covered by a thinner layer of the same carbonate

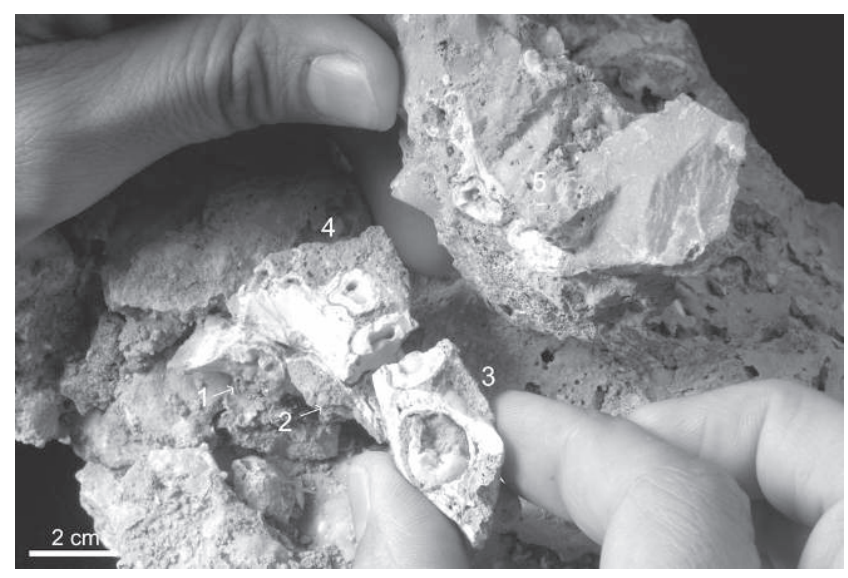

Figure 1: Mandible ATD6-112 before treatment. It was broken into six pieces (numbered to document the conservation process). Fragment 1 (hereafter, F1, etc.) contains the symphysis and part of the germs of the permanent canine (C) and second incisor (I2). F2, almost imperceptible in this image, consists in part of the mandibular corpus including part of the germ of the canine. F3 contains the permanent first molar (M1) and a half of the decidual second molar $(\mathrm{dm} 2)$; the other half of the $\mathrm{dm} 2$ is in F4, which also contains the root of the decidual first molar $(\mathrm{dm} 1)$, the sockets of the canine and the lateral incisor, and the unerupted central incisor. In F5, the two crowns of the decidual molars (dm 1 and $\mathrm{dm} 2$ ) are completely embedded in the sediment. Picture by J. Mestre - IPHES.

Figure 1 : Mandibule ATD6-112 avant le traitement. Elle était brisée en six morceaux (numérotés afin de documenter le processus de restauration). Le fragment 1 (ci-après, $F 1$, et ainsi de suite) contient la symphyse et une partie des germes de la canine permanente $(C)$ et la deuxième incisive (I2). F2, presque imperceptible sur cette image, consiste en une partie du corps mandibulaire, y compris une partie du germe de la canine. F3 contient les premières molaires permanentes (M1) et une moitié de la deuxième molaire déciduale (dm2); l'autre moitié de la dm2 est dans F4, qui contient également la racine de la première molaire déciduale (dm1), les alvéoles de la canine et de l'incisive latérale, et l'incisive centrale n'ayant pas fait éruption. En F5, les deux couronnes des molaires déciduales (dm1 et dm2) sont complètement englobées dans le sédiment. Photographie J. Mestre-IPHES.

sediment. The reconstruction of the fossil did not present any problems but, during breakage some of the material at the contact areas came loose which made it impossible to conjoin some parts, specifically the two molars ( $\mathrm{dm} 1$ and $\mathrm{dm} 2$ ). In addition, the excavation process resulted in microcracking in some parts of the fossil, especially those most affected by impacts and the associated vibrations (such as, again, the molars $\mathrm{dm} 1$ and $\mathrm{dm} 2$ ). This microcracking, along with the extreme thinness of some of the parts (e.g. the alveolar process), added to the difficulty of eliminating the sediment. Therefore, the main problem we were faced with when deciding on a preparation procedure was that we 
had a delicate specimen with thin areas and microcracks that was partially embedded in a hard matrix. Due to its fragmentation, several transversal planes of the specimen could be observed without needing any additional examination technique (such as CT scan).

We prepared the specimen mainly using a CTS Art Piezo piezoelectric ultrasonic scaler (supplied by CTS España). Although this device is from a supplier specialising in conservation equipment, it has the same technical characteristics as the scalers often used by dentists to remove hard calculus deposits and stains. It is electric powered and must also be connected to a water or air source for cooling. Its control unit has ultrasonic power settings and air or water flow regulators (the cooling system). It has a hand-piece for which different tips (three in this model) can be chosen and its output power ranges from $20 \mathrm{~V}$ A to $30 \mathrm{kHz}$. According to the supplier information, the ultrasound waves cause the tip to vibrate with minimum oscillation for precision control. In the presence of water it generates cavitation, the same effect by which ultrasound baths clean, thus increasing the power of the tool. For the preparation of mandible ATD6112 , we used the device with air as a coolant because using water would get the fossil excessively wet and flood the work area. We used all three types of tips supplied for this model. The tips have slightly different shapes and vary in thickness to allow more or less detailed action, which proved very useful for this task.

\section{Results}

The specimen was cleaned primarily with the ultrasonic scaler, although occasionally and for limited areas other tools were also used. Specifically, when the scaler was not powerful enough to remove the extremely hard sediment, we used a pneumatic scribe. On the other hand, in some areas where the vibrations of the scaler were too strong, such as on some parts of the alveolar process and other thin parts, we used a scalpel instead. However, most of the sediment was removed by means of the ultrasonic scaler (Fig. 2). This tool allowed us to separate the fossil from the block sediment and perform the final cleaning. As a result, we obtained a well cleaned fossil, without any remarkable damage due to the preparation process (Fig. 3).

After the cleaning process, we ended up with seven fragments instead of the original six pieces: fragment number 5 was converted into two pieces because of the individualisation of the two molars. All the fragments fit well, with the exception of these two molars, which lost part of the material at the contact area between the crown (embedded into

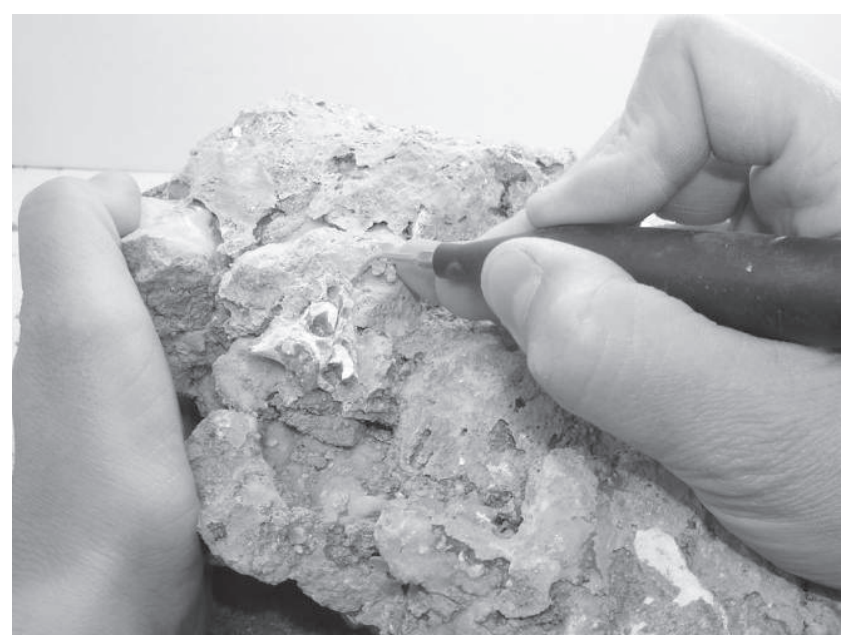

Figure 2: Working with the ultrasonic scaler: removing fragment 1 from the matrix. Picture by A.Ollé - IPHES.

Figure 2 : Travail au détartreur à ultrason: dégagement du fragment 1 de la matrice. Photographie A. Ollé - IPHES.

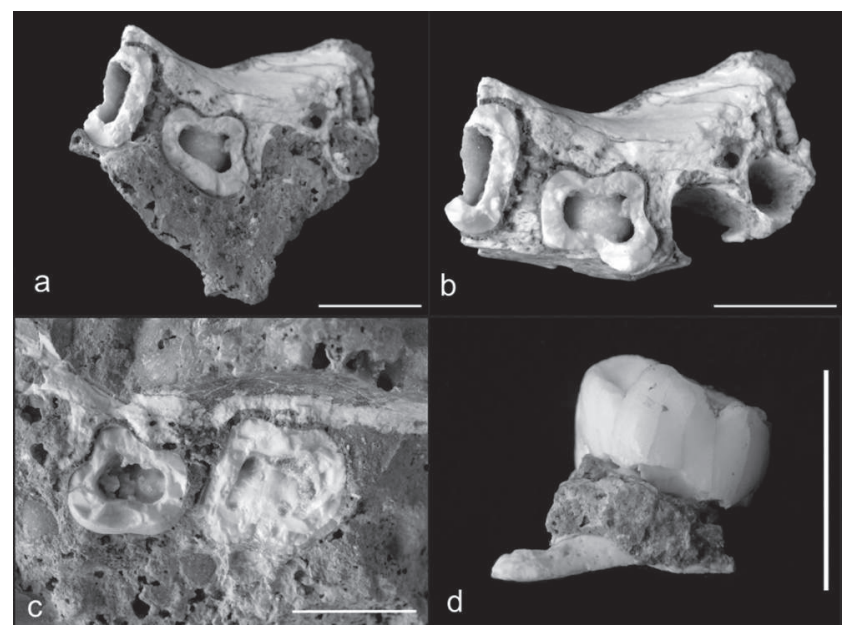

Figure 3: Fragments 4 and 5 before (a, c) and after (b, d) removing the sediment. In F4, the ultrasonic scaler allowed the sediment to be removed from the fragile and reduced area of the tooth sockets (a, b). In F5, we can observe the sectioned crown of the two molars (c); breakage in this part involved the loss of some small fragments of the teeth and microcracking of the remaining material. The molars were recovered separately because the remains of the alveolar bone were almost imperceptible and thus unsalvageable. Final aspect of the dm1 (d). Picture by L. López-Polín - IPHES. Figure 3 : Fragments 4 et 5 avant $(a, c)$ et après $(b, d)$ le dégagement du sédiment. Sur F4, le détartreur à ultrason a permit de retirer le sédiment de la zone réduite et fragile des alvéoles dentaires $(a, b)$. Sur F5, on peut observer la couronne sectionnée des deux molaires (c); la cassure dans cette zone a impliqué la perte de quelques petits fragments de dents et la microfissuration de la matière restante. Les molaires ont été récupérés séparément, car les restes de l'os alvéolaire étaient presque imperceptible et donc irrécupérables. Aspect final de la dm1 (d). Photographie L. López-Polin - IPHES. 
a block of sediment) and the roots, included in a different bone fragment. This loss was present before the preparation treatment began, having occurred during the excavation process, and thus does not constitute an effect of the preparation process or the ultrasonic scaler itself. Although these two molars would need some filling material to perfectly fit them in place, the remainder of the pieces fit perfectly (Fig. 4). Nevertheless, in order to facilitate the subsequent palaeoanthropological study, none of the fragments of this mandible were adhered and a virtual reconstruction of the fossil was created from the 3D image of each piece (Bermúdez de Castro et al., 2010).

\section{Discussion and Conclusion}

The aim of this paper was to contribute to publicising the possibilities of the ultrasonic scaler in the preparation of fossil bones. The tool was used to clean a human mandible embedded in a hard matrix of carbonated clay that was firmly joined to its surface. The fossil had many delicate areas covered and filled by this sediment; the alveolar process

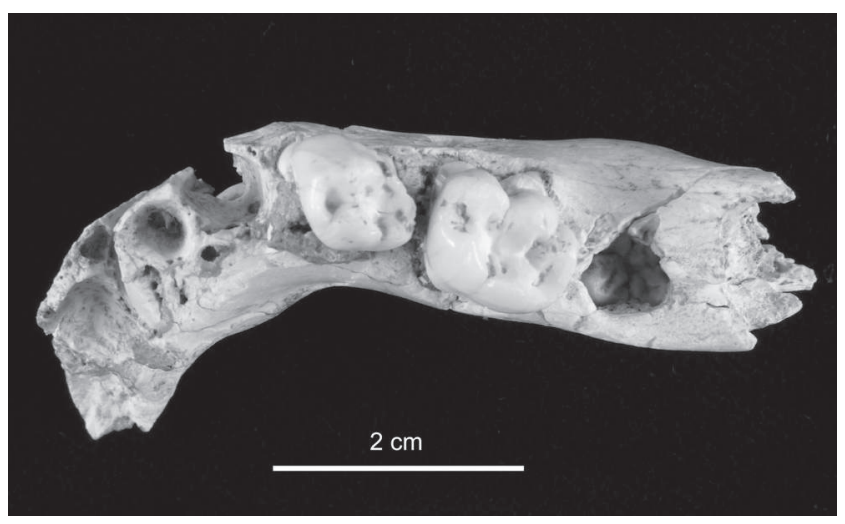

Figure 4: Mandible after the cleaning process. Superior view with the two molars ( $\mathrm{dm} 1$ and $\mathrm{dm} 2)$ in place. The fragments fit well, with the exception of the two molars: the loss of material at the basis of these elements prevented the perfect refit at the end of the restoration process (they would need some filling material in the event of a final restoration). The mandible was left unadhered to facilitate the subsequent palaeoanthropological study. Picture by L. López-Polín - IPHES.

Figure 4 : Mandibule après le processus de nettoyage. Vue supérieure avec les deux molaires (dm1 et dm2) en place. Les fragments sintègrent bien, à l'exception des deux molaires: la perte de matériel à la base de ces dents a empêché la remise en état parfaite à la fin du processus de restauration (cela nécessiterait l'utilisation de matériaux de remplissage dans le cas d'une restauration finale). La mandibule a été laissée sans coller les fragments afin de faciliter l'étude paléoanthropologique ultérieure. Photographie L. López-Polin-IPHES. was especially difficult to clean due to the thinness of the alveolar bone and the small dimensions of the tooth sockets. The combination of hard matrix and delicate, thin parts of the fossil led us to rule out the possibility of using some of the more forceful tools available to us (such as the pneumatic engraver) and, at the same time, to choose a tool that would be more powerful than the scalpel (or similar tools).

The ultrasonic scaler was designed for use in the field of dentistry. There are therefore some drawbacks that we think may be due to the lack of the tool's adaptation to preparation work. To begin with, the apparatus needs to be cooled by a continuous jet of water or air. In accordance with the supplier's instructions, the specific model that we used can be connected to an air compressor. We performed the preparation in this way, but the tips nevertheless got warm very quickly, meaning that we often had to stop working to allow them to cool down. Apart from this, continuous air projection can be a problem for treating some specimens, as it immediately disperses the debris, so the conservator must pay attention and stop working if detachments occur. Another problem was that the tips wore down quite quickly, especially when we treated the hardest areas. Of course, the more frequently we have to replace the tip, the more expensive the treatment is. Tip wear might be decreased through modifications such as those suggested by some authors, in which an ultrasonic scaler was adapted by replacing the tip with a carbide rod. In addition, this new, straight tip seems to be more suitable for this type of work than the original curved tips (Fedak, 2000). However, we did not test these alternative tips and we therefore did not check their efficacy. Finally, another disadvantage worth mentioning is that the ultrasonic scaler generates vibrations that, despite being milder than those produced by the pneumatic engraver, can be too intense for some purposes. For example, in this specific case, we had to use the scalpel instead of the scaler on some parts of the tooth sockets which were too reduced and fragile for the vibrations of the tip.

We have detailed the disadvantages in order to better assess the cleaning method, but in fact the ultrasonic scaler was the solution to our problem, as it allowed us to remove the hard and firmly adhered sediment from the more delicate parts of the specimen, and also allowed us to empty the small tooth sockets that would be difficult to hollow out using any other tool.

To conclude, the ultrasonic scaler can be more efficient than the scalpel or other similar small tools, although it is sometimes too time consuming or inefficient for removing carbonated clay matrixes. On the other hand, it is more precise than more powerful tools. Therefore, the ultrasonic scaler is worth considering for some preparation purposes, 
as it is a good intermediate option between small tools such as scalpels or other small tools and more powerful tools such as chisels or pneumatic air scribes.

\section{Acknowledgements}

We acknowledge all the members of the Atapuerca Research Team involved in the recovery and study of the archaeopaleontological record. Field work is supported by Junta de Castilla y León and Fundacion Atapuerca. The preparation of the fossil ATD6-112 was developed at the IPHES (Tarragona), where many people enrich our work on a daily basis. This research has been developed in the framework of the Spanish MICINN project CGL2009-12703-C03-02. Thanks to the two reviewers for their useful comments.

\section{References}

Berguer, W. G., Pérez-González, A., Carbonell, E., Arsuaga, J. L., Bermúdez de Castro, J. M. and Ku, T. L., 2008. Luminescence chronology of cave sediments at the Atapuerca paleoanthropological site, Spain. Journal of Human Evolution, 55 (2): 300-311.

Bermúdez de Castro, J. M., Arsuaga, J. L., Carbonell, E., Rosas, A., Martínez, I. and Mosquera, M., 1997. A hominid from the Lower Pleistocene of Atapuerca, Spain: possible ancestor to Neandertals and modern humans. Science, 276: 1392-1395.

Bermúdez de Castro, J. M., Martinón-Torres, M., Prado, L., Gómez-Robles, A., Rosell, J., López-Polín, L., Arsuaga, J. L. and Carbonell, E., 2010. New immature hominin fossil from European Lower Pleistocene shows the earliest evidence of a modern human dental development pattern. PNAS, 107: 11739-11744.

Carbonell, E., Bermúdez de Castro, J. M., Arsuaga, J. L., Díez, J. C., Rosas, A., Cuenca, G., Sala, R., Mosquera, M. and Rodríguez, X. P., 1995. Lower Pleistocene hominids and artifacts from Atapuerca-TD6 (Spain). Science, 269: 826-830.

Carbonell, E., Esteban, M., Martín Nájera, A., Mosquera, M., Rodríguez, X. P., Ollé, A., Sala, R., Vergès, J. M.,
Bermúdez de Castro, J. M. and Ortega, A. I., 1999. The Pleistocene site of Gran Dolina, Sierra de Atapuerca, Spain: a history of the archaeological investigations. Journal of Human Evolution, 37: 313-324.

Falguères, C., Bahain, J.-J., Yokoyama, Y., Arsuaga, J. L., Bermudez de Castro, J. M., Carbonell, E., Bischoff, J. L. and Dolo, J.-M., 1999. Earliest humans in Europe: the age of TD6 Gran Dolina, Atapuerca, Spain. Journal of Human Evolution, 37: 343-352.

FedaK, T. J., 2000. The Creation of a Micro-Scribe for the Preparation of Small, Delicate Fossil Material. Society of Vertebrate Paleontology Technical Papers, 1. From [http://www. vertpaleo.orgleducation/preptechpapers1.cfm].

Green, O. R., 2001. A Manual of Practical Laboratory and Field Techniques in Paleobiology. Kluwer Academic Publishers, Dordrecht.

Jakobsen, S. L. and Feldman, R. M., 2004. Epibionts on Dromiopsis rugosa (Decapoda: Brachyura) from the late middle Danian limestones at Fakse Quarry, Denmark: novel preparation techniques yield amazing results. Journal of Paleontology, 78: 953-960.

lópez-Polín, L., Ollé, A., Cáceres, I., Carbonell, E. and Bermúdez de Castro, J. M., 2008. Pleistocene human remains and conservation treatments: the case of a mandible from Atapuerca (Spain). Journal of Human Evolution, 54: 539545.

May, P., Reser, P. and Leiggi, P., 1994. Laboratory preparation. Macrovertebrate preparation. In P. Leiggi \& P. May (Eds.) Vertebrate paleontological techniques. Cambridge University Press, Cambridge, 113-129.

Parés, J. M. and Pérez-González, A., 1995. Paleomagnetic age for hominid fossils at Atapuerca archaeological site, Spain. Science, 269: 830-832.

Rixon, A. E., 1976. Fossil Animal Remains. Their preparation and conservation. University of London, London.

Wilson, J., 1995. Conservation and processing - cleaning and mechanical preparation. In C. Collins (Ed) The Care and Conservation of Palaeontological Material. ButterworthsHeinemann, Oxford, 89-94. 